\title{
The Evolving Status of NGOs under International Law: A Threat to the Inter-State System?
}

Citation for published version (APA):

Kamminga, M. T. (2005). The Evolving Status of NGOs under International Law: A Threat to the InterState System? In P. Alston (Ed.), Non-State Actors and Human Rights (pp. 93-111). Oxford University Press.

Document status and date:

Published: 01/01/2005

Document Version:

Publisher's PDF, also known as Version of record

Document license:

Taverne

Please check the document version of this publication:

- A submitted manuscript is the version of the article upon submission and before peer-review. There can be important differences between the submitted version and the official published version of record.

People interested in the research are advised to contact the author for the final version of the publication, or visit the DOI to the publisher's website.

- The final author version and the galley proof are versions of the publication after peer review.

- The final published version features the final layout of the paper including the volume, issue and page numbers.

Link to publication

\footnotetext{
General rights rights.

- You may freely distribute the URL identifying the publication in the public portal. please follow below link for the End User Agreement:

www.umlib.nl/taverne-license

Take down policy

If you believe that this document breaches copyright please contact us at:

repository@maastrichtuniversity.nl

providing details and we will investigate your claim.
}

Copyright and moral rights for the publications made accessible in the public portal are retained by the authors and/or other copyright owners and it is a condition of accessing publications that users recognise and abide by the legal requirements associated with these

- Users may download and print one copy of any publication from the public portal for the purpose of private study or research.

- You may not further distribute the material or use it for any profit-making activity or commercial gain

If the publication is distributed under the terms of Article $25 \mathrm{fa}$ of the Dutch Copyright Act, indicated by the "Taverne" license above, 


\title{
The Evolving Status of NGOs under International Law: A Threat to the Inter-State System?
}

\author{
MENNO T. KAMMINGA*
}

\section{InTRODUCTION}

Non-governmental organizations (NGOs) appear to be subjected to increasing criticism. Unlike criticisms made in the past, they are coming from sources that deserve to be taken quite seriously.

Judge Gilbert Guillaume, the current President of the International Court of Justice, in 1996 took the unusual step of publicly criticizing the role played by NGOs in the context of the Court's advisory opinion on the legality of nuclear weapons. In an individual opinion, he expressed his unease about the role played by the International Association of Lawyers against Nuclear Arms (IALANA) and other groups in bringing pressure to bear on the Assemblies of the United Nations and the World Health Organization in order to induce them to refer a request for an advisory opinion to the Court. He also criticized these groups for organizing letter-writing campaigns aimed at the judges of the Court. ${ }^{1}$ He posed the question whether under such circumstances the requests for opinions emanating from the Assemblies could still be regarded as coming from the bodies that had adopted them or whether the Court should not have dismissed them as inadmissible. He expressed the hope 'that Governments and inter-governmental institutions [would] still retain sufficient independence of decision to resist the powerful pressure groups which besiege them today with the support of the mass communication media'. ${ }^{2}$

Serge Sur, Professor at the University of Paris II, has expressed similar concern at the 'excessive' role played by NGOs at the Rome Conference that in 1998 adopted the Statute of the International Criminal Court. He pointed out that at the Conference NGO representatives were true partners in the negotiations,

\footnotetext{
* The author gratefully acknowledges the research assistance provided by Tania van Dijk.

1 In his dissenting opinion, Judge Weeramantry reported that the Court had received well over three million signatures from NGOs and individuals in connection with this case: The Legality of the Threat or Use of Nuclear Weapons, advisory opinion [1996] ICJ Rep. at 216, dissenting opinion of Judge Weeramantry, text accompanying n. 3 .

2 Ibid., individual opinion of Judge Guillaume, para. 2.
} 
either indirectly by putting pressure on delegations or directly by being members of governmental delegations and being allowed to speak on their behalf. According to Professor Sur, in Rome States in effect abandoned their monopoly on inter-State negotiations. ${ }^{3}$ The influence exerted by NGOs is also reflected in the Statute of the International Criminal Court itself. Under Article 15(2), the Court's Prosecutor may 'seek additional information from States, organs of the United Nations, inter-governmental or non-governmental organizations, or other reliable sources that he or she deems appropriate' (emphasis added). Professor Sur expressed his astonishment at the fact that NGOs are thereby put on the same level as States and inter-governmental organizations. He wondered whether by allowing NGOs to put pressure on the International Criminal Court in this way the Court does not risk being reduced to a People's Tribunal. ${ }^{4}$

The journal The Economist recently asked the question whether citizens' groups really are the first steps towards an 'international civil society' or whether they represent a dangerous shift of power to unelected and unaccountable special-interest groups. The journal posed this question in direct response to the mayhem caused by NGOs at the World Trade Organization summit meeting in Seattle in 1999. But it also pointed to the important role played by NGOs in pushing through the climate convention at the Earth Summit in Rio de Janeiro in 1992, the convention banning landmines in 1997, and in sinking the Multilateral Agreement on Investment (MAI) in 1998.5

What these critics seem to be saying is that the influence of NGOs on the international plane has been growing out of all proportion, that special interest groups cannot be expected to balance all relevant interests, that only States can be relied upon to do so, that while it may be right for pressure groups to exercise their influence within States they should not be allowed to do so on the international plane, that unlike States (democratic States that is) NGOs are accountable to no one. In sum, the fear expressed by these observers is that NGOs have become so effective that they are beginning to present a threat to the Westphalian inter-State system.

While some of these complaints belong to the realm of political science, some of the points made by Guillaume and Sur appear to be suitable for legal scrutiny. Is it true, as Judge Guillaume seems to suggest, that NGOs are now in a position to manipulate the International Court of Justice for their own ends? Is it correct, as Professor Sur seems to imply, that international standard-setting conferences these days are at the mercy of NGOs? This raises familiar but rarely systematically addressed questions about the status of NGOs in international law. Brownlie lists the following traditional indicators of legal personality in international law: capacity to make claims in respect of breaches of international

3 S. Sur, 'Vers une Cour pénale internationale: la Convention de Rome entre les ONG et le Conseil de sécurité' (1999) 103 RGDIP 29 at 35-6.

4 Sur, above n. 3 , at 37-8.

5 'The Non-Governmental Order: Will NGOs Democratise, or Merely Disrupt, Global Governance?', The Economist, 11 Dec. 1999, 18-19. 
law, capacity to make treaties and agreements valid on the international plane, and the enjoyment of privileges and immunities from national jurisdictions. ${ }^{6}$ Following a slightly different subdivision, we will consider the capacity of NGOs to conclude treaties (including treaties conferring privileges and immunities), their capacity to participate in treaty-making, their capacity to bring international claims, and their capacity to incur liability under international law. But first we need to define the subject of our enquiry, for what is an NGO is not at all self-evident.

\section{What IS AN NGO?}

Despite the increasing importance of NGOs in international law-making and enforcement, international law does not offer an authoritative definition of nongovernmental organizations. Much confusion surrounds the subject. For example, a frequently quoted article in the Encyclopedia of Public International Law suggests that the concept of NGOs may encompass multinational corporations or even national liberation movements. ${ }^{7}$ This clearly confuses NGOs with the wider concept of non-State actors.

The only relevant treaty in this area is the European Convention on the Recognition of the Legal Personality of International Non-Governmental Organizations adopted by the Council of Europe in $1986 .{ }^{8}$ In spite of its promising title, the Convention does not establish a procedure for the recognition of the international legal personality of NGOs on the international plane. It merely provides that the legal personality acquired by an NGO in the State party in which it has its statutory office shall also be recognized in the other States parties. ${ }^{9}$ The Convention therefore does not alter the fact that NGOs, if they have any legal status at all, have such status only under domestic law. ${ }^{10}$ Significantly, NGOs themselves were not consulted during the drafting of this treaty. A questionnaire was distributed to NGOs in 1967 , with a view to identifying any problems experienced by them. ${ }^{11}$ But it remains quite unclear what problems the respondents identified and therefore precisely which defects the Convention was trying to remedy. The Convention's Explanatory Report refers to problems

6 I. Brownlie, Principles of Public International Law (1998) 57.

7 H.H.-K. Rechenberg, 'Non-Governmental Organizations' in R. Bernhardt (ed.), 3 Encyclopedia of Public International Law (1997) 612 at 612.

824 Apr. 1986, ETS No. 124, entered into force 1 Jan. 1991. Only 9 of the 44 member States of the Council of Europe have become parties so far: Austria, Belgium, France, Greece, Macedonia, Portugal, Slovenia, Switzerland, and the UK.

9 Ibid., Art. 2.

10 N. Rodley, 'Human Rights NGOs: Rights and Obligations (Present Status and Perspectives)' in T. van Boven et al. (eds.), The Legitimacy of the United Nations: Towards an Enhanced Legal Status of Non-State Actors (1997) 45.

11 M.O. Wiederkehr, 'La Convention européenne sur la reconnaissance de la personnalité juridique des organisations internationales non gouvernementales du 24 avril 1986' (1995) 47 Transn'l. Ass'ns 181 at 181. 
caused by activities in several countries, meetings being held in diverse places and personnel being employed of various nationalities ${ }^{12}$ but it is difficult to see how this would be sufficient justification for the adoption of a Convention, particularly within Western Europe.

NGOs are most easily defined by explaining what they are not. First and foremost, NGOs are private structures in the sense that they are not established or controlled by States. This distinguishes NGOs from inter-governmental organizations (IGOs). ${ }^{13}$ Secondly, NGOs do not seek to overthrow governments by force. This distinguishes them from liberation movements and armed opposition groups. Thirdly, while NGOs may seek to change government policies they do not aim to acquire State power themselves. This distinguishes NGOs from political parties. Fourthly, while NGOs may be engaged in fundraising and merchandizing activities they do not seek financial profit for their own sake. This distinguishes NGOs from companies. Fifthly, while some NGOs may occasionally engage in civil disobedience, they are generally lawabiding. This distinguishes NGOs from criminal organizations. ${ }^{14}$

Any attempt to define NGOs in positive rather than negative terms is problematic beyond the observation that they tend to be private citizens' groups established to further certain common objectives of their members. ${ }^{15}$ The objectives pursued by NGOs differ considerably. Examples range from groups working for the common good, such as environmental and human rights groups, to special interest groups, such as trade unions and business associations. In terms of strategies employed by NGOs, a distinction may be made between organizations engaged in advocacy or campaigning, such as Greenpeace and Human Rights Watch, and organizations engaged in relief and assistance, such as CARE and Save the Children. Some organizations, such as Oxfam, combine the two functions. In practice, there appears to be a tendency of NGOs to become more involved in advocacy. Médecins sans Frontières, initially set up as an aid agency, after some soul-searching a few years ago decided to also engage in advocacy

\footnotetext{
12 Explanatory Report on the European Convention on the Recognition of the Legal Personality of International Non-Governmental Organizations (1986), para. 1.

13 There are, however, some hybrid NGOs, such as the ICRC and IUCN, that include States or State agencies among their members or as members of their governing councils. See below n. 15 .

$14 \mathrm{On}$ the difference between NGOs and criminal organizations see A. Schmid, 'Non-State Actors: Organized Crime, Human Rights NGOs and the United Nations' in van Boven et al. (eds.), above n. 10, 125. Art. 2(a) of the UN Convention against Transnational Organized Crime, adopted on 15 Nov. 2000, defines an 'organized criminal group' as 'a structured group of three or more persons, existing for a period of time and acting in concert with the aim of committing one or more serious crimes or offences established in accordance with this Convention, in order to obtain, directly or indirectly, financial or other material benefit': UN Doc. A/55/383.

15 Even this modest description is not entirely correct. Some organizations, such as the International Union for the Conservation of Nature (IUCN), the International Committee of the Red Cross (ICRC), and the International Federation of Red Cross and Red Crescent Societies, accept governmental authorities as members of their highest bodies. Under para. 12 of ECOSOC Resolution 1996/31 on the consultative relationship between the United Nations and nongovernmental organizations, these organizations are nevertheless regarded as NGOs.
} 
under certain circumstances. Even a typical aid organization such as the Red Cross Movement has been debating whether to get involved in advocacy. ${ }^{16}$

NGOs are usually thought of as having an international character, with members and branches in more than one country and with objectives that are not limited to one State. This is the approach underlying the European Convention on the Recognition of the Legal Personality of International NonGovernmental Organizations and ECOSOC Resolution 1296 (XLIV) of 23 May 1968 on consultative relations between the United Nations and NGOs. However, the new ECOSOC Resolution 1996/31 of 25 July 1996, which replaces Resolution 1296, specifically provides that consultative relations may also be established with national organizations. ${ }^{17}$ In that case, the views of the Member State in question must first be sought before they may be admitted to consultative status. ${ }^{18}$ ECOSOC has thereby belatedly brought its relations with NGOs in conformity with UN Charter Article 71, which provides that consultative arrangements of ECOSOC with NGOs may, where appropriate, include relations with national organizations.

It is sometimes assumed that NGOs are a recent invention, that they began to emerge after the Second World War. In fact, the history of NGOs stretches back more than 200 years, starting with associations established at the end of the eighteenth century in the United States, France, and the United Kingdom to bring an end to the slave trade. The Anti-Slavery Society, which is still active today, was established in the United Kingdom in 1839. It has been suggested that the role of NGOs may be cyclical, with reductions in importance during the two World Wars and a resurgence after each of these. The role of NGOs appears to have reached new heights during the 1990s, inter alia because of the many new issues (environment, development, international criminal law) appearing on the international agenda on which governments require the input and support from NGOs. ${ }^{19}$

In terms of the resources available to them the significance of NGOs is now certainly on the increase. More than 1,600 NGOs currently have consultative status with ECOSOC. But this is only one indicator. The number of domestic NGOs probably runs into the millions. NGOs have also grown considerably in size, in terms both of their membership and of their budgets.

Globalization has clearly been one of the main contributing factors to this growth. NGOs engaged in campaigning have greatly benefited from the sharply increased popularity of the Internet. This has helped to undermine the governmental monopoly on information. It has also made it much easier to mobilize people across the globe in favour of or against certain causes, ${ }^{20}$ as was demonstrated for example by the scuppering of the MAI. NGOs engaged in aid

\footnotetext{
16 P. Nobel, 'The Role of the International Red Cross and Red Crescent Movement in Promoting Respect for Human Rights' (1993) 293 Int'l Rev. Red Cross 146.

17 Above n. 15, para. 5.

19 S. Charnovitz, 'Two Centuries of Participation: NGOs and International Governance' (1997) 18 Mich. J Int'l L 183 at $268-70$.

20 See J. Matthews, 'Power Shift' (1997) 76 Foreign Aff. 51.
} 
and relief have benefited from the currently prevailing view that such assistance can often more effectively be distributed through private agencies. As a result, many States have re-routed their aid and relief flows to NGOs. NGOs collectively now deliver more aid than the entire United Nations system does. ${ }^{21}$

\section{Capacity to conclude treaties}

NGOs, if they have any legal status at all, tend to enjoy such status under domestic law only. It follows that they generally have no capacity to perform legal acts on the international plane. In particular they do not have the capacity to conclude treaties with States. This distinguishes NGOs from other non-State actors, such as inter-governmental organizations and multinational corporations, which do enjoy (limited) treaty concluding capacity. There are, however, a number of notable exceptions.

Switzerland, as a host State for numerous international organizations, both inter-governmental and non-governmental, has adopted an interesting practice of defining the international status of NGOs in agreements with them that sometimes are indistinguishable from treaties under international law. These agreements demonstrate a flexible and pragmatic approach on the part of the Swiss authorities. No doubt underlying this practice has been their desire to maintain the attractiveness of the country as a seat for international institutions.

A prime example is the headquarters agreement concluded in 1993 between Switzerland and the International Committee of the Red Cross (ICRC), an association established under Swiss law. ${ }^{22}$ This agreement explicitly recognizes the international juridical capacity of the ICRC and grants it privileges and immunities very similar to those enjoyed by IGOs. Accordingly, it provides that the ICRC and its staff are immune from legal process and that the ICRC's premises are inviolable. It also contains provisions on the settlement of disputes by way of arbitration, with the President of the International Court of Justice appointing a chairperson if the arbitrators appointed by the two parties are unable to agree on such an appointment between themselves. The ICRC has concluded comparable agreements with more than sixty States in which its delegations are located. ${ }^{23}$ The International Federation of Red Cross and Red Crescent Societies has concluded similar headquarters agreements with more than thirty States, including Switzerland. ${ }^{24}$ There can be little doubt that all

21 L. Gordenker and T. Weiss, 'NGO Participation in the International Policy Process' (1995) 16 Third World Q. 543 at 554.

22 Agreement between the International Committee of the Red Cross and the Swiss Federal Council to determine the legal status of the Committee in Switzerland, 19 Mar. 1993 (1993) 293 Int'l Rev. of the Red Cross 152.

23 ICRC Annual Report 1998, available on www.icrc.org.

24 See P. Gautier, 'O.N.G. et personnalité internationale: à propos de l'Accord conclu le 29 novembre 1996 entre la Suisse et la Fédération internationale des Sociétés de la Croix-Rouge et du Croissant-Rouge' (1997) 30 Revue belge de droit international 172. 
these agreements qualify as treaties under international law. ${ }^{25}$ There are two main reasons for the unusual facilities enjoyed by the ICRC and the Federation. First, the ICRC has been provided with special responsibilities under Articles 9 and 10 of the First, Second, and Third Geneva Conventions and under Articles 10 and 11 of the Fourth Geneva Convention. Furthermore, States parties to the Geneva Conventions participate in the International Red Cross Conference, the highest Red Cross organ.

The special status of the Red Cross organizations has also been recognized by the UN General Assembly. The Assembly granted observer status to the ICRC in $1990^{26}$ and to the International Federation of Red Cross Societies in 1994. ${ }^{27}$ The ICRC and the Federation are the only NGOs enjoying this status and the General Assembly clearly intends to keep it that way. During the same session in which it granted observer status to the Federation it decided that 'the granting of observer status in the General Assembly should in the future be confined to States and to those inter-governmental organizations whose activities cover matters of interest to the Assembly'. ${ }^{28}$

Some other NGOs based in Switzerland at first sight appear to qualify for similar status because of their special character. However, they have benefited from considerably less privileged treatment. The International Union for the Conservation of Nature is an unusual NGO that counts sixty-eight States and ninety-two government agencies among its members. More than 80 per cent of its budget derives from governments and IGOs. Nevertheless, the agreement Switzerland concluded with the IUCN in 1986 cannot be regarded as a proper headquarters agreement. It merely covers freedom of taxation for the IUCN and its foreign staff. ${ }^{29}$ The International Olympic Committee is an association under Swiss law. ${ }^{30}$ It counts no States among its members. In the early 1980s, attempts were made by the IOC to have its international legal personality recognized by the Swiss authorities and even by the UN General Assembly. ${ }^{31}$ These efforts were not successful. The Swiss Federal Council adopted a mere decree

25 C. Dominicé, 'La personnalité juridique internationale du CICR' in C. Swinarski (ed.), Studies and Essays on International Law and Red Cross Principles in Honour of Jean Pictet (1984) 663 at 668-9. In the same vein see P. Reuter, 'La personnalité juridique internationale du Comité international de la Croix-Rouge', ibid. 783 at 790-1.

26 UNGA Res. 45/6, 16 Oct. 1990. See C. Koenig, 'Observer Status for the International Committee of the Red Cross at the United Nations: A Legal Viewpoint' (1991) 280 Int'l Rev. Red Cross 37.

27 UNGA Res. 49/2, 19 Oct. 1994. See W. Remans, 'The Granting of Observer Status by the General Assembly of the United Nations to the International Federation of Red Cross and Red Crescent Societies' in K. Wellens (ed.), International Law: Theory and Practice. Essays in Honour of Eric Suy (1998) 347-62.

28 GA Res. 49/426, 9 Dec. 1994.

29 R.S. Imhoof, 'La personnalité juridique et le statut des institutions de caractère international: exemples tirés de la pratique suisse' (1989) 46 Annuaire suisse de droit international 93 at 107-8.

30 Art. 19 of the Olympic Charter.

31 D.J. Ettinger, 'Comment: The Legal Status of the International Olympic Committee' (1992) 4 Pace YB Int'l L 108-9. Surprisingly, however, the author concludes that the Committee does have international legal status. 
(not an agreement) noting the importance for Switzerland of having the IOC within its borders but confirming the organization's status under Swiss rather than international law. ${ }^{32}$

It may be deduced that States are willing to conclude treaties on an equal footing with NGOs if this suits their interests. This occurs on an ad hoc basis if the NGO in question resembles an IGO by having States among its members or because it resembles a State by having State-like functions. Clearly, such agreements bind only the parties, they do not create entitlements vis-à-vis third States.

\section{Capacity to participate in treaty-making}

At inter-governmental conferences NGOs generally do not enjoy the capacity to participate in the drafting of international instruments. Law-making on the international plane is a privilege that tends to be reserved for States. In line with this principle, ECOSOC Resolution 1996/31, the key UN resolution on consultative relations between ECOSOC and non-governmental organizations, specifically prohibits NGOs from engaging in 'negotiations'. ${ }^{33}$

A major exception to this rule, however, is the role played by workers' and employers' representatives in the International Labour Organization. Unlike in other IGOs, in the ILO workers' and employers' representatives participate on an equal footing with representatives from States. Under the ILO's tripartite system, each State is represented by four delegates, of whom two are government representatives and one each represents the employers and the workers of that State. This means that at the ILO employers' and workers' representatives have the same capacity as government representatives to participate in the drafting of conventions and other international instruments adopted by the ILO. This facility has certainly enabled these organizations to leave their mark on standardsetting within that organization. ${ }^{34}$

It is nevertheless doubtful whether the ILO presents an attractive model for the integration of NGOs into international law-making. ${ }^{35}$ First, under Article $3(5)$ of the ILO Constitution, employers' and workers' delegates are selected by the governments of the States in question. This power obviously creates possibilities for abuse because many States lack employers' and workers' organizations that are independent of the government. Under Article 3(9) of the ILO Constitution the credentials of delegates at the Conference may be challenged,

32 Unpublished decree of 8 July 1981, referred to by Imhoof, above n. 29, 104 and quoted by Ettinger, above n. 31, 103-4.

33 'In recognition of the intergovernmental nature of the conference and its preparatory process, active participation of non-governmental organizations therein, while welcome, does not entail a negotiating role': ECOSOC Res. 1996/31, 25 July 1996, para. 50.

34 Charnovitz, above n. 19, 216-19.

35 See V. Leary, 'The ILO: A Model for Non-State Participation?' in van Boven et al. (eds.), above n. 10,60 . 
but this happens very rarely. ${ }^{36}$ Secondly, while the ILO is very welcoming to workers' and employers' organizations, it is most inaccessible to other NGOs that have an interest in its activities, such as human rights organizations. ${ }^{37}$ Interestingly, it is not so much the government representatives at the ILO that resist participation from NGOs but the workers and the employers, for the apparent reason that broadening access to the ILO might undermine their own privileged position. As a result, the ILO runs the risk of becoming a rather inward-looking organization that excludes perspectives from the non-corporate world.

In spite of their limited formal status at IGO meetings, in practice NGOs often play a key role in creating awareness of the need to adopt international instruments and even in the drafting of such instruments. This is not a new development. The role of NGOs in international standard-setting stretches back to the role of the Anti-Slavery Society and other anti-slavery organizations in the nineteenth century in pressing for the adoption of treaties for the suppression of the slave trade. ${ }^{38}$ But it seems fair to say that this role has continuously increased since the Second World War. It is no exaggeration to suggest that some of the most important international legal instruments of recent years would not have seen the light without the input of NGOs. This role may range from a mere stimulating role to the participation in drafting exercises as full participants with a right to make proposals on an equal footing with States. As the subject matter of multilateral treaties is becoming more and more complex, States depend on NGOs to provide information and expertise, which they or the Secretariats of IGOs may not have readily available themselves. States may also use NGOs to try out certain ideas that they are not yet prepared to defend themselves or they may employ NGOs to help break a deadlock. NGO input into the drafting of international instruments has been especially crucial in the fields of human rights, ${ }^{39}$ the environment, ${ }^{40}$ and, more recently, disarmament. In furthering their international law-making objectives, NGOs have developed three broad strategies that may be labelled as high level approaches, campaigning, and coalition building. Combinations of these strategies have become routine features at international standard-setting conferences.

The International Commission of Jurists (ICJ), a small Geneva-based NGO consisting of senior judges and lawyers from different parts of the world, is a

36 Leary, above n. 35, 71.

${ }^{37}$ I speak from my own experience as a representative of Amnesty International at International Labour Conferences.

38 Charnovitz, above n. 19, 191-2.

39 See, generally, T. van Boven, 'The Role of Non-Governmental Organizations in International Human Rights Standard-Setting: A Prerequisite of Democracy' (1990) 20 Cal. W Int'l LJ 207; and C. Chinkin, 'The Role of Non-Governmental Organisations in Standard Setting, Monitoring and Implementation of Human Rights' in J.J. Norton, M. Andreas, and M. Footer (eds.), The Changing World of International Law in the Twenty-First Century: A Tribute to the Late Kenneth R. Simmons (1998) 51.

${ }^{40}$ See, generally, D. Tarlock, 'The Role of Non-Governmental Organizations in the Development of International Environmental Law' (1992) 10 Chi.-Kent L. Rev. 61. 
good example of an organization that has very effectively employed high-level approaches aimed directly at State representatives. The adoption in 1981 of the African Charter on Human and Peoples' Rights can clearly be attributed to the ICJ. ${ }^{41}$ Seminars for African jurists convened by the ICJ in Lagos in 1961 and in Dakar in 1977 recommended the creation of an African convention on human rights. Approaches to African heads of State by senior participants of the latter seminar resulted in a decision by these heads of State to appoint a drafting committee to prepare an African human rights instrument. Keba Mbaye, President of Senegal's Supreme Court and President of the ICJ, was appointed as its rapporteur. ${ }^{42}$

A different convention, the European Convention for the Prevention of Torture, adopted in 1987, was a joint initiative of the ICJ and another NGO, the Swiss Committee against Torture. ${ }^{43}$ The idea behind this Convention-routine visits to places of detention by independent international observers in order to prevent the occurrence of torture-was conceived by Jean-Jacques Gautier, the President of the Swiss Committee. The text of the Convention adopted by the Council of Europe was closely based on a draft prepared at the Council of Europe's request by the ICJ and the Swiss Committee. ${ }^{44}$

The 'elitist' strategy followed by the ICJ was highly effective in these two instances because that was all that was required to convince key government representatives of the need to adopt these new international instruments. Such a strategy would probably have been insufficient to secure the adoption of a strong UN Convention against Torture in 1984.45 The role of Amnesty International and the International Commission of Jurists in the negotiations themselves clearly was important. ${ }^{46}$ However, because of its sensitive subject matter, it is unlikely that a decent Convention would have been adopted without the simultaneous campaigning of Amnesty International sections around the world. They drew attention to the widespread character and brutal nature of torture and to the need to recognize torture as a crime under international law.

Partly overlapping with the drafting of the Convention against Torture was the drafting of the UN Convention on the Rights of the Child. ${ }^{47}$ Apparently

41 African Charter on Human and Peoples' Rights, Nairobi, 27 June 1981 (1982) 21 ILM 58.

42 See H. Tolley, 'Popular Sovereignty and International Law: ICJ Strategies for Human Rights Standard Setting' (1989) 11 HRQ 561 at 578-9 and N. MacDermot, 'Le rôle des organisations non gouvernementales dans l'élaboration des normes relatives aux droits de l'homme' (1992) 90/1 Bull. des droits de l'homme 44 at $44-5$.

43 European Convention for the Prevention of Torture and Inhuman or Degrading Treatment or Punishment, Strasbourg, 26 Nov. 1987 (1988) 27 ILM 1152.

44 See above n. 42, Tolley, 571-2 and MacDermot, 46.

45 UN Convention against Torture and Other Cruel, Inhuman or Degrading Treatment or Punishment, New York, 10 Dec. 1984 (1984) 23 ILM 1027.

46 On the role played by Amnesty International see V. Leary, 'A New Role for NonGovernmental Organizations in Human Rights: A Case Study of Non-Governmental Participation in the Development of International Norms on Torture' in A. Cassese (ed.), UN Law/Fundamental Rights (1979) 197-206.

47 Convention on the Rights of the Child, New York, 20 Nov. 1989 (1989) 18 ILM 1448. 
because governments regarded its subject matter as less sensitive, the drafting of this Convention permitted more room for input by NGOs. In order to maximize their impact, NGOs interested in this Convention adopted a technique that has since become a virtual tradition at international standard-setting exercises: the creation of an NGO coalition. In 1983, twenty-three NGOs established the Informal NGO Ad Hoc Group on the Drafting of the Convention of the Rights of the Child. ${ }^{48}$ The Group developed detailed textual proposals that were laid down in reports that were highly influential during the negotiations. Governments frequently turned to the Group for drafting assistance on difficult aspects of the text. It has been suggested that the imprint of the NGO Group can be found in almost every provision of the Convention. ${ }^{49}$ Following the adoption of the Convention, the Group reconstituted itself into the NGO Group for the Convention on the Rights of the Child. This new Group has a more formal structure with several thematic subgroups. Its activities include various types of assistance to the Committee on the Rights of the Child established under the Convention to monitor its implementation. ${ }^{50}$

In the environmental field, NGOs played a crucial role in the adoption of the 1992 Framework Convention on Climate Change. ${ }^{51}$ During the drafting of this Convention in Rio de Janeiro and also at subsequent follow-up meetings, NGOs contributed very effectively by using their expertise in direct contacts with delegates and by addressing the plenary session from the floor. ${ }^{52}$ Environmental NGOs that were particularly involved in this forum include the World Wildlife Fund (WWF), Greenpeace, the Environmental Defence Fund, the Sierra Club, Ozone Action, and the WorldWatch Institute. ${ }^{53}$ Some of these organizations co-ordinated their positions in an umbrella organization called Climate Action Network, currently encompassing more than 160 NGOs. An equally important role, however, is being played by business organizations such as the Climate Council, the Global Climate Coalition, and the World Business Council for Sustainable Development. Despite their promising names, these are umbrella organizations for fossil fuel producers and related industries. ${ }^{54}$

Another example of a highly successful NGO coalition is the International Campaign to Ban Landmines (ICBL). The ICBL was created in 1992 by six NGOs: Handicap International, Human Rights Watch, Medico International, Mines Advisory Group, Physicians for Human Rights, and the Vietnam Veterans of America Foundation..$^{55}$ It currently has more than 1,100 member

48 C. Price Cohen, 'The Role of Nongovernmental Organizations in the Drafting of the Convention on the Rights of the Child' (1990) 12 HRQ 137.

49 Price Cohen, above n. 48, 142.

50 C. Price Cohen, 'The United Nations Convention on the Rights of the Child: Involvement of NGOs' in van Boven et al. (eds.), above n. 10, 181-4.

51 Framework Convention on Climate Change, New York, 9 May 1992 (1992) 31 ILM 849.

52 C. Giorgetti, 'The Role of Nongovernmental Organizations in the Climate Change Negotiations' (1998) 9 Colo. J Int'l Envtl. L \& Pol'cy 115 at 126.

53 Giorgetti, above n. 52, 127.

55 J. Williams and S. Goose, 'The International Campaign to Ban Landmines' in M. Cameron et al. (eds.), To Walk Without Fear: The Global Movement to Ban Landmines (1998) 20 at 22; R. Price, 
organizations. Until the ICBL began its activities, it was a little-known fact that anti-personnel mines kill or maim hundreds of innocent civilians, especially children, every week. The ICBL managed to put the phenomenon on the international map as a global crisis requiring a radical but simple response, i.e. a comprehensive ban on landmines. No doubt, the horrific character of its message and the simplicity of the proposed remedy were essential elements of the Campaign's success. A Convention providing for a total ban on the use, stockpiling, production, and transfer of anti-personnel mines was duly adopted in 1997 and entered into force in $1999 .{ }^{56}$ The Convention was arrived at in a highly innovative way. The usual method of international standard-setting employs consensus as the method of decision-making and tends to be dominated by the great powers. In 1996, Canada took the lead in adopting a new approach involving 'like-minded States' and working closely with NGOs. ${ }^{57}$ This method of avoiding the slowest-boat rule obviously allows considerably more scope for input by NGOs. ${ }^{58}$

The 'like-minded States' approach to standard-setting was also adopted at the 1998 Rome Conference on the Statute of an International Criminal Court. ${ }^{59}$ The Like Minded Group included over sixty States that were committed to a strong Court. They worked closely with the NGO Coalition for an International Criminal Court. ${ }^{60}$ The NGO Coalition, founded in 1995, eventually grew to a movement of more than 800 organizations, of which Amnesty International, Human Rights Watch, the Lawyers Committee for Human Rights, and the Women's Caucus for Gender Justice in the ICC were among the most active, not only in Rome but also during the three years of preparations for this Conference. ${ }^{61}$ During the five weeks of the Rome Conference, the Coalition and its individual member organizations prepared detailed briefing papers, divided into thirteen working groups on the 128 Articles of the Statute, held regular meetings with governments and weekly meetings with the Conference Chair, provided expert advice and translations to governments, convened regional and sectoral caucuses, provided the Conference's only two daily newspapers, and organized media briefings. ${ }^{62}$ The role played by NGOs in support

'Reversing the Gun Sights: Transnational Civil Society Targets Landmines' (1998) 52 Int'l. Org. 613 at 620 .

56 Convention on the Prohibition of the Use, Stockpiling, Production and Transfer of AntiPersonnel Mines and on their Destruction, Oslo, 18 Sept. 1997 (1997) 36 ILM 1507.

57 K. Anderson, 'The Ottawa Convention Banning Landmines, the Role of International Nongovernmental Organizations and the Idea of International Civil Society' (2000) 11 EJIL 91-120, at 107.

58 See M. Dolan and C. Hunt, 'Negotiating in the Ottawa Process: The New Multilateralism' in Cameron et al. (eds.), above n. 55, 392.

59 Statute of the International Criminal Court, Rome, 17 July 1998 (1998) 37 ILM 999.

60 P. Kirsch, 'Introduction' in H. von Hebel et al. (eds.), Reflections on the International Criminal Court (1999) 1 at 3.

61 W. Pace, 'The Relationship between the International Criminal Court and Non-Governmental Organizations' in ibid., 200-5.

62 Ibid. 
of a strong International Criminal Court was therefore of a more sophisticated nature than the role of NGOs during the negotiations of the Landmines Convention. Unlike the Landmines Convention, the Rome Statute is a highly complicated legal instrument that required considerable technical drafting skills that many governmental delegates did not possess. Rome therefore represented yet another milestone in the contribution of NGOs to international lawmaking.

An analysis of the text of these conventions does not reveal any apparent resentment on the part of States of the role played by NGOs in the adoption of these instruments. On the contrary, in an apparent acknowledgement of the importance of NGO input, the conventions often provide NGOs with a formal role in their implementation and follow-up. The Convention on the Rights of the Child provides that its supervisory body may invite 'competent bodies' to provide expert advice on the implementation of the Convention. ${ }^{63}$ The Climate Convention contains a remarkably liberal admissions policy for follow-up conferences. It provides that any non-governmental body 'which is qualified in matters covered by the Convention, and which has informed the secretariat of its wish to be represented at a session of the Conference of the Parties as an observer, may be so admitted unless at least one-third of the Parties present object'. ${ }^{64}$ The Landmines Convention provides that NGOs may be invited to attend meetings of the States Parties and Review Conferences. ${ }^{65}$ The Statute of the International Criminal Court provides that the Prosecutor may seek additional information, inter alia from NGOs. ${ }^{66}$

\section{CAPACITY TO BRING INTERNATIONAL ClAimS}

NGOs do not generally have the legal capacity to bring international claims against States alleging a breach of obligations owed to them. The first reason for this is of course that States tend not to owe any international legal obligations at all to NGOs. But even if such obligations exist, they can usually not be enforced on the international plane.

For example, the headquarters agreement concluded in 1947 between the United Nations and the United States provides that the authorities of the United States 'shall not impose any impediments to transit to or from headquarters district of ... representatives of . . non-governmental organizations recognized by the United Nations for the purpose of consultation under Article 71 of the Charter'. ${ }^{67}$ However, in case of non-compliance on the part of the United States

63 Art. 45(a), UN Convention on the Rights of the Child.

64 Art. 7(6), UN Framework Convention on Climate Change.

65 Art. 11(4) and 12(3), Landmines Convention.

66 Art. 15(2), Rome Statute of the International Criminal Court.

67 S. 11, Agreement between the United Nations and the United States of America regarding the Headquarters of the United Nations, Lake Success, 26 Jun. 1947, 147 UNTS 11 at 20. 
(something which has occurred from time to time ${ }^{68}$ ) the agreement does not enable NGOs to take legal action against the USA on the international plane.

There are nevertheless some instances in which States have accepted international obligations towards NGOs that are enforceable in this way. As we have seen above, representatives of the ICRC enjoy significant privileges and immunities on a par with representatives of IGOs, which may be enforced through international arbitration. ${ }^{69}$ Furthermore, under Article 34 of the European Convention on Human Rights NGOs have a right to lodge petitions to the European Court of Human Rights claiming to be victims of violations of the rights set forth in the Convention. A wide range of associations has submitted applications under this provision. ${ }^{70}$

Moreover, some international mechanisms of a semi-judicial nature permit NGOs to lodge complaints even if they themselves have not been victims of a violation. Accordingly, under the ILO's freedom of association procedure, complaints may be lodged not only by workers' or employers' organizations directly interested but also by any international workers' or employers' organization having consultative status with the ILO. Complaints are considered by the Committee on Freedom of Association, which reports to the ILO's Governing Body. $^{71}$

Comparable to this mechanism is the procedure established recently by the Additional Protocol to the European Social Charter Providing for a System of Collective Complaints. Pursuant to this Protocol, NGOs are entitled to bring 'complaints alleging unsatisfactory application of the Charter'. ${ }^{72}$ Such complaints are considered by a Committee of Independent Experts, which may draw up a report for the Council of Europe's Committee of Ministers. The right to lodge such complaints is restricted to employers' and workers' organizations and certain other NGOs that have been put on a special list. The first complaint after the entry into force of the Protocol, alleging child labour in Portugal, was filed by the International Commission of Jurists. A more liberal regime creating access for a wider range of NGOs is offered by the American Convention on Human Rights. Under its Article 44, an NGO 'legally recognised in one or more Member States of the organisation, may lodge petitions with the [InterAmerican Commission on Human Rights] containing denunciations or complaints of violation of this Convention by a State Party'.

Under some international mechanisms NGOs enjoy the possibility of thirdparty intervention. This does not amount to the ability to bring international claims, but it may offer important possibilities to influence the development of

68 H. Schermers and N. Blokker, International Institutional Law (1995) 242.

69 Text accompanying n. 22.

70 See P. van Dijk and G. van Hoof, Theory and Practice of the European Convention on Human Rights (1998) 46.

71 See the website of the ILO: www.ilo.org.

72 Art. 1, Additional Protocol to the European Social Charter Providing for a System of Collective Complaints, 9 Nov. 1995 (1995) 34 ILM 1453. 
international law. ${ }^{73}$ Accordingly, while NGOs cannot be parties in contentious proceedings before the International Court of Justice, under Article 66 of the Court's Statute they may receive permission to submit relevant information to the Court in connection with requests for advisory opinions. In practice, however, the Court has been extremely reluctant to permit NGOs to take advantage of this facility. ${ }^{74}$ The International League for Human Rights in 1950 received such permission in connection with the South-West Africa advisory proceedings but the League's subsequent submissions were declared inadmissible by the Court for various procedural reasons. ${ }^{75}$

Regional human rights courts have been more forthcoming. ${ }^{76}$ Under Article 36(2) of the European Convention on Human Rights (until recently Article 36(2) of the Rules of Court) the President of the European Court of Human Rights may invite 'any person concerned who is not the applicant to submit written comments or take part in hearings'. Amicus curiae briefs have so far been filed in dozens of cases, mostly by NGOs based in the United Kingdom, such as Amnesty International, Article 19, INTERIGHTS, and Justice. The information and arguments included in these briefs usually play an important role in the Court's proceedings. ${ }^{77}$ NGOs may also submit amicus curiae briefs to the InterAmerican Court of Human Rights both in contentious cases and with regard to requests for advisory opinions. The Inter-American Court has generally been more welcoming towards NGOs than the European Court. ${ }^{78}$

Finally, and lowest in the legal hierarchy but not necessary lowest in terms of practical importance, NGOs often play an essential role also in more informal ways, by bringing relevant information to the attention of (members of) international monitoring bodies. ${ }^{79}$ This possibility may be specifically provided for in the relevant treaty or resolution, or it may be contained in the monitoring body's rules of procedure or it may not be based on any formal rule at all.

73 See D. Shelton, 'The Participation of Nongovernmental Organizations in International Judicial Proceedings’ (1994) 88 AJIL 611.

74 Ibid., 619-28.

75 Roger S. Clark, 'The International League for Human Rights and South West Africa 1947-1957: The Human Rights NGO as Catalyst in the International Legal Process' (1981) 3 HRQ 101 at $116-21$.

76 See, generally, M. Ölz, 'Non-Governmental Organizations in Regional Human Rights Systems' (1997) 28 Colum. Hum. Rts. L Rev. 307.

77 M. Nowicki, 'NGOs before the European Commission and Court of Human Rights' (1996) 14 NQHR 239 at 297. Shelton, above n. 73, 638, finds the significance of amicus briefs 'difficult to evaluate'.

78 See D. Padilla, 'The Inter-American Commission on Human Rights of the Organization of American States: A Case Study' (1993) 9 Am. U J Int'l. L \& Pol'y 95 at 111 and Shelton, above n. 73, at 638-40.

79 See P.H. Kooijmans, 'The Non-Governmental Organizations and the Monitoring Activities of the United Nations in the Field of Human Rights' in The Role of Non-Governmental Organizations in the Promotion and Protection of Human Rights: Symposium Organized on the Occasion of the Award of the Praemium Erasmianum to the International Commission of Jurists (1989) 15-22. 


\section{Liability UNDER INTERNATIONAL LAW}

Since NGOs, even international NGOs, tend to be established merely under domestic law, they can generally be held accountable only under domestic law. Accordingly, NGOs may be sued under domestic law for libel or for damage caused, for example by having published erroneous reports. Moreover, organizations such as Greenpeace are frequently being sued for their acts of civil disobedience.

Can an NGO also be held liable under international law if it acts contrary to an international obligation incumbent upon it? This first raises the question whether international law imposes any obligations at all on NGOs.

The Declaration on the Right and Responsibility of Individuals, Groups and Organs of Society to Promote and Protect Universally Recognized Human Rights and Fundamental Freedoms, adopted by the UN General Assembly in 1999, in spite of its promising title does not contain any significant obligations for NGOs. ${ }^{80}$ The Declaration merely provides that NGOs have 'an important role to play and a responsibility' in promoting human rights and the right of everyone to a social and international order. It is unlikely that any liability under international law could ever be based on these provisions, even if it were assumed that they contain binding obligations.

Some UN resolutions appear to assume that NGOs are bound by the purposes and principles of the UN Charter. The Declaration and Programme of Action adopted at the Vienna World Conference on Human Rights provides that NGOs may not exercise the rights and freedoms of the Universal Declaration of Human Rights contrary to the purposes and principles of the United Nations. ${ }^{81}$ ECOSOC Resolution 1996/31 on the consultative relationship between the United Nations and non-governmental organizations similarly provides that an NGO may be deprived of its consultative status if it abuses its status by engaging in 'a pattern of acts contrary to the purposes and principles of the Charter of the United Nations including unsubstantiated or politically motivated acts against Member States of the United Nations incompatible with those principles and purposes' ${ }^{82} \mathrm{~A}$ comparable provision was included in its predecessor resolution, ECOSOC Resolution $1296 .{ }^{83}$

It is difficult to see, however, how an NGO could breach a purpose or a principle contained in the UN Charter. The only principle of the Charter that could conceivably be infringed by an NGO is the prohibition of intervention in internal affairs contained in Article 2(7). However, Article 2(7) is addressed to the United Nations. While it is generally assumed that a similar obligation rests on

80 GA Res. 53/144, 8 Mar. 1999.

81 Vienna Declaration and Programme of Action, 25 Jun. 1993 (1993) 32 ILM 1673.

82 Above n. 15, para. 57(a).

83 Para. 36(b). 
individual States ${ }^{84}$ there is no authoritative evidence of a similar obligation incumbent on NGOs. ${ }^{85}$

On the basis of the penalty provisions contained in ECOSOC Resolutions 1296 and 1996/31, two NGOs have nevertheless been deprived of their consultative status so far. The International Lesbian and Gay Association (ILGA) had its Roster status suspended in 1994 after the United States had complained that one of its US affiliates was advocating paedophilia. ${ }^{86}$ The United States may not have realized that this decision might open a Pandora's box. Christian Solidarity International (CSI) had its consultative status revoked in 1999 at the insistence of Sudan because it had been represented by a Sudanese rebel leader, John Garang, at a session of the UN Commission on Human Rights. ${ }^{87}$ This decision was taken in spite of the fact that Resolution 1996/31 requires a pattern of violations as a condition for the withdrawal of status. The decision was not, as is usually the case in ECOSOC, taken by consensus but by a majority (twenty-six in favour to fourteen against, with twelve abstentions)..$^{88}$

These decisions by ECOSOC apparently mark a significant change in its attitude towards NGOs. They seem to indicate a greater willingness on the part of Sates to assume that NGOs may be held accountable and that they should pay a heavy price for even minor transgressions. During the 1970s and 1980s States accused by NGOs of human rights abuses at the UN Commission on Human Rights frequently complained about alleged abuses of consultative status. Some of these complaints were similar to those being made against CSI. For example, in 1977 Argentina complained about a representative of a 'terrorist' organization being allowed to make statements on behalf of the International Commission of Jurists and Pax Romana. However, neither on that occasion nor on other occasions in that period was there any significant support among States for the withdrawal of consultative status of the NGOs in question. ${ }^{89}$

\section{Conclusions}

NGOs play an increasingly important role on the international plane, and to some extent this is being reflected in their formal status. Some 'hybrid' NGOs have concluded treaties with States and they enjoy privileges and immunities similar to those of IGOs. In some instances, NGOs are also able to bring international claims against States. Perhaps most spectacularly, NGOs more and

${ }^{84}$ See e.g. GA Res. 2625 (XXV), 24 Oct. 1970.

85 It has been suggested that Charter Art. 71 prevents Art. 2(7) from being invoked against NGOs: A. Drzemczewski, 'The Role of NGOs in Human Rights Matters in the Council of Europe' (1987) 8 Hum. Rts. LJ 273 at 274. However, this seems like a redundant and in any case not very convincing argument.

86 ECOSOC Res. 1994/50. $\quad 87$ Press Release ECOSOC/5876. 88 Ibid.

${ }^{89}$ M. Kamminga and N. Rodley, 'Direct Intervention at the UN: NGO Participation in the Commission on Human Rights and its Sub-Commission' in H. Hannum (ed.), Guide to International Human Rights Practice (1984) 186 at 189 and 192-7. 
more play a crucial role in the drafting of international instruments and in the follow-up and monitoring of those instruments. This latter role has frequently been enshrined in treaties and other formal arrangements.

However, the extent of these developments should not be exaggerated. The formal status of NGOs under international law is still extremely weak. At the United Nations, NGOs can still only have consultative relations with ECOSOC and not with bodies that matter, such as the Security Council and the General Assembly. Discussions on the involvement of NGOs in international economic fora such as the World Trade Organization (WTO) are still in their infancy. ${ }^{90}$ Moreover, States are still in full control of access to the international system. NGOs may at any time be deprived of their right to act on the international plane if they are perceived, rightly or wrongly, to have misbehaved. States appear to be increasingly willing to invoke this sanction. After decades in which no NGO was deprived of its consultative status with ECOSOC two NGOs were recently stripped of their consultative status, on highly arbitrary grounds and with scant respect for the procedures laid down for this purpose by ECOSOC itself.

There is therefore little evidence that States will ever allow NGOs to become a serious threat to the inter-State system. NGOs would in any case begin to present such a threat only if their role were increasing at the expense of the role played by States or if they set out to establish a rival system of world government. There is simply no indication that this is happening. The mayhem caused by demonstrators at WTO conferences may look threatening but as long as the participants do not have a clear vision of an alternative international system the worry seems rather misplaced.

If and when NGOs are permitted to participate in international decisionmaking, they are allowed to do so because they help to strengthen rather than weaken the inter-State system. By contributing the views of civil society, they confer badly needed legitimacy on the international system. International decisions taken without the input of NGOs risk remaining unimplemented because they lack the required degree of public support. By contributing expertise NGOs also help to improve the quality of international decisions. Many subjects of international conferences have become so technical that numerous States, not only the smaller ones, find it hard to muster the necessary know-how. Furthermore, by providing their information and expertise for free NGOs offer significant savings to the inter-State system. Many underfunded IGO pro-

90 See, e.g., S. Charnovitz, 'Participation of Nongovernmental Organizations in the World Trade Organization' (1996) 17 Un. Pa. J Int'l Econ. L 331; D. Esty, 'Non-Governmental Organizations at the World Trade Organization: Cooperation, Competition, or Exclusion' (1998) $1 \mathrm{~J}$ Int'l Econ. L 123; W. Benedek, 'Developing the Constitutional Order of the WTO-The Role of NGOs' in W. Benedek, H. Isak, and R. Kicker (eds.), Developing and Development of International and European Law: Essays in Honour of Professor Konrad Ginther (1999) 313; G. Marceau and P. Pedersen, 'Is the WTO Open and Transparent? A Discussion of the Relationship of the WTO with Non-governmental Organisations and Civil Society's Claims for More Transparency and Public Participation' (1999) 33 J World Trade 5. 
grammes would not be able to carry out meaningful activities without the substantive input received from NGOs.

Important decisions affecting the daily lives of citizens around the world are made at international meetings by faceless bureaucrats and representatives of highly undemocratic nations. ${ }^{91}$ Giving NGOs a role in international governance may not, at first sight, be a satisfactory remedy for this unsatisfactory state of affairs. To begin with, it should be frankly admitted that NGOs are not by definition praiseworthy. NGOs may serve special and limited interests that are not necessarily laudable. The objectives of some groups are excessively narrow or even discriminatory or racist. ${ }^{92}$

Moreover, anyone can establish an association and call it an NGO. The claim to be non-governmental should therefore not be accepted at face value. There are numerous subtle and less subtle ways in which States may influence individual NGOs. For example, in order to operate NGOs often require official registration by the authorities of the States in which they are located. This means they must meet the criteria laid down by the authorities. Or they may acquire tax-exempt status only if they meet certain criteria established by the host State. Furthermore, many NGOs depend on government funds even for their core activities.

Finally, many NGOs, even those committed to promoting democracy and good governance, are far from democratic themselves. Few NGOs have regular internal elections and fewer still have policies that are determined democratically by their members. Some consist of only one or two people. As a result, the representatives of many NGOs at international conferences may be expected to push their own agendas rather than those of their constituents. Their claims to being representatives of civil society should be taken with a considerable pinch of salt. ${ }^{93}$

However, reality is not as depressing as might seem to follow from such a recital of the failings of NGOs. Unlike States, NGOs derive their authority not simply from their existence but from their individual qualities. NGOs that are not perceived as working for the common good, that are not entirely independent of governments, and that have no mechanisms for internal accountability will attract few individual supporters and little funding and will have little impact on the international plane. Of course, this does not prevent such NGOs from being vocal but volume should not be confused with influence. NGO coalitions, an instrument created by NGOs themselves, also have an important moderating effect. They are unlikely to endorse sectarian positions from marginal groups because this would risk undermining their own credibility. On the other hand, positions that manage to become part of an NGO platform-especially

91 Van Boven, above n. 39, 223.

92 O. Schachter, 'The Decline of the Nation-State and its Implications for International Law' (1997) 36 Colum. J Transnat'l L 7 at 14.

93 Gordenker and Weiss, above n. 21, 553. See also P.J. Simmons, 'Learning to Live with NGOs' (1998) 120 Foreign Pol'y 82 at 83. 
when it is a platform shared by a varied group of hundreds of NGOs-may legitimately be regarded as the views of civil society.

In sum, there continues to be much more reason for concern about the negative impact of 'irresponsible' governments than about 'irresponsible' NGOs. The formal and informal checks on the influence of NGOs on the international plane are such that there is no need for a general system of appellation contrôlée under international law. 